\title{
Apparent Induction of Xylanase by Bacillus pumilus PU4-2 using Pretreated Substrates
}

\author{
SHERLY WIDJAJA ${ }^{1}$, TRESNAWATI PURWADARIA²*, AND PIUS PERTUMPUN KETAREN² \\ ${ }^{1}$ Faculty of Biotechnology, Universitas Katolik Indonesia Atma Jaya, \\ Jalan Jenderal Sudirman 51, Jakarta 12930, Indonesia \\ ${ }^{2}$ Indonesia Research Institute for Animal Production, PoBox 221, Bogor 16002, Indonesia
}

\begin{abstract}
Bacillus pumilus PU4-2 produces xylanase ( $\beta$-1,4-D-xylan xylanohydrolase; EC 3.2.1.8) in wheat pollard with high activity. Water and $\mathrm{NaOH}$-soaked pollard were used in this research to enhance the production of assayable enzyme. Enzyme activity was produced in minimal media containing $3 \% \mathrm{w} / \mathrm{v}$ untreated or water or $\mathrm{NaOH}$-soaked pollards in $250 \mathrm{ml}$ flasks incubated on shaker incubator at $30^{\circ} \mathrm{C}$ and $150 \mathrm{rpm}$ for $36 \mathrm{~h}$. The production was also compared to untreated oatmeal known as an inducer substrate. The highest xylanase activity was obtained by using untreated pollard as a sole carbon source. The enzyme activity was $157 \mathrm{U} \mathrm{ml}^{-1}$ with specific activity at $718 \mathrm{U} \mathrm{mg}^{-1}$. Xylanase production using different soaking time for water pretreated pollard also confirmed that untreated pollard was the best inducer. The production was not influenced by different water soaking times used to remove reducing sugar. Although pretreatment decreased the reducing sugar, the reduction did not enhance assayable enzyme levels. The production was best induced by the soluble oligosaccharides of untreated pollard. We conclude that B. pumilus PU4-2 was able to produce xylanase with reducing sugar content up to $660 \mathrm{ppm}$ present in production medium. With this reducing sugar level, repression of enzyme production was not detected in the production medium.
\end{abstract}

Key words: xylanase, Bacillus pumilus PU4-2, wheat pollard, pretreatment

Plant cell walls are the major reservoir of fixed carbon sources in nature. They have three major components consisting of cellulose (insoluble fibers of $\beta$-1,4-glucan), hemicellulose (noncellulosic polysaccharides including glucans, mannans, and xylans), and lignin (a complex polyphenolic structure) (Wong et al.1988; Tuncer 2000). These structures commonly referred as lignocellulose with each concentration a variable; cellulose 30-45, hemicellulose 30, and lignin 15-30\% w/ ${ }_{w}$, respectively (Tuncer 2000).

Xylan is one of the major polysaccharides, along with cellulose of higher plants. The abundance of xylan clearly indicates that xylanolytic enzymes can play an important role in bioconversion. The composition and structure of xylan varies according to the sources. However, all the xylans are heteropolysaccharides with homopolymeric backbone chains of â-1,4-D-xylopyranose units. The xylose backbones are substituted with mainly acetyl, arabinosyl, and glucuronosyl residues, depending on the source (Tuncer 2000). As a result of this molecular complexity, the simultaneous and synergistic action of a range of bioactive enzymes is required to complete the degradation process. The enzyme that plays a key role on xylan degradation is endo- $\beta-1,4-D-x y l a n a s e$ ( $\beta$-1,4-D-xylan xylanohydrolase; EC 3.2.1.8) that randomly cleaves $\beta$-1,4-glycosidic bonds to produce xylooligosaccarides and -1,4-D-xylosidase ( $\beta$-1,4-D-xyloside xylohydrolase; EC 3.2.1.37) that cleaves the terminal part of short xylo-oligosaccharides to produce free xylose (Flores et al. 1997).

Kinds of substrate including monosaccharides, oligosaccharides or poly saccharides influence the production of xylanase by Sclerotium rolfsii (Sachslehner et al. 1998). The highest assayable xylanase activity is observed from ácellulose or bacterial cellulose, while other polysaccharides

${ }^{*}$ Corresponding author, Phone: +62-251-240752/3, Fax: +62-22-2504154, E-mail: tpurwadaria@yahoo.co.uk such as xylan birchwood, carboxymethyl cellulose or galactomannan induces lower activities. Disaccharides, such as xylobiose and cellobiose induced more enzyme production than monosaccharides (xylose, glucose, and mannose).

Xylanase was successfully produced in the minimal medium containing wheat pollard (Purwadaria et al. 2004a). Wheat pollard used as substrate in this research was naturally found as a by-product from the flour milling process. As a biomass residue, wheat pollard can be used to produce other material with higher economic value such as a source for enzyme production, animal feed or even as a biofuel. Ketaren et al. (2002) reported that pollard supplemented with xylanase could be used as a feed ration for animal diets. The application of enzymes such as xylanase in poultry diets could eliminate anti-nutritive properties of cereal grains presently being used as major ingredients of animal feed (Chocht 2006).

It was reported that pretreatments, especially soaking in sodium hydroxide, enhanced the cellulase production (Purwadaria et al. 2004b). This result correlated with lignocellulose content that had been altered by sodium hydroxide where it breaks the lignin shield and disrupts the crystalline structure of cellulose (Shin et al. 2000; Mosier et al. 2005). Soaking pollard in water might reduce the reducing sugar availability in pollard or decrease the catabolite repression of enzymes. Meanwhile, it was reported that oatmeal was able to minimize cholesterol levels in the blood due to its high fiber content. This material could also be used as substrate for enzyme production (Irawan 1999). As a material with high fiber content, oatmeal could be preferably used as substrate for xylanase production.

Bacillus pumilus was reported able to produce xylanase, $\beta$-xylosidase, acetylxylanesterase (Degrassi et al. 1998), and cellulase (Kotchoni et al. 2003). Besides these abilities, $B$. pumilus has been employed in industry for alkaline protease production, in the environmental 
decontamination of dioxins (Hong et al. 2001), in the baking industry (Nuyens et al. 2001), and in the adsorption of halogenated aromatic pollutants (Choi et al. 2003). B. pumilus PU4-2 was a strain which was isolated by Purwadaria et al. (2004a) from the gut of Termitidae that had xylanolytic activity. Besides microorganisms, plants (Lima et al. 2001) can also produce xylanase. Microbial xylanases are preferred because of their high specificity in enzyme reactions, the mild reaction condition used and the absence of substrate loss due to chemical modifications (Wong et al. 1988).

The objective of this study was to investigate the effect of pretreatment methods on the endo- $\beta-1,4-D$-xylanase production by $B$. pumilus PU4-2. It was of special interest to analyze the correlation between reducing sugar and inducer molecules and their effect on the assayable enzyme levels.

\section{MATERIALS AND METHODS}

Material. Wheat pollard, used as substrate for this research, was obtained from ISM Bogasari Flour Mills. Oat spelt xylan was purchased from Sigma Aldrich.

Organism and Culture. Bacillus pumilus PU4-2 isolated from gut of Termitidae (Purwadaria et al. 2004a) is from a collection of the Indonesian Research Institute for Animal Production. The bacteria were maintained on nutrient agar containing $0.1 \%$ oat spelt xylan.

Experimental Procedures. Pollard used as substrate for the first experiments were (i) pollard pretreated by soaking in water, (ii) pollard pretreated by soaking in sodium hydroxide, (iii) untreated pollard as control, and (iv) oatmeal as a comparator. Water-soaked pollard was obtained by soaking pollard $(5 \% \mathrm{w} / \mathrm{v})$ using water over one hour. At the end of one hour, the pollard was filtered using cotton cloth and dried overnight in an oven at $45^{\circ} \mathrm{C}$. The dried pollard is then ready to use as substrate for enzyme production. Sodium hydroxide soaked-pollard was obtained by soaking pollard $(5 \% \mathrm{w} / \mathrm{v})$ in $0.5 \% \mathrm{w} / \mathrm{v}$ sodium hydroxide solution. This mixture was boiled for one hour. After this time the pollard was then washed with water until it reached neutral $\mathrm{pH}$. The pollard was then filtered and dried. Both water and $\mathrm{NaOH}$-soaked pollard were ground in a blender. In the second group of experiments, the enzyme activity in untreated pollard (control) and pollard soaked in water for 5, 10, 15, and 20 minutes were carried out. All treatments were repeated three times and enzyme levels were assayed after the treatment periods.

Enzyme Production. Eighteen-hours old cultures of B. pumilus PU4-2 grown on agar slants were resuspended by adding $5 \mathrm{ml}$ of $\mathrm{NaCl} 0.85 \%$ w/. Xylanase was produced by adding $2 \mathrm{ml}$ of inoculum to $50 \mathrm{ml}$ PM liquid minimal medium (Purwadaria et al. 2004a) which added with
$0.05 \% \mathrm{w} / \mathrm{v}$ yeast extract, $0.075 \% \mathrm{w} /{ }_{\mathrm{v}}$ peptone, and $3 \% \mathrm{w} /{ }_{\mathrm{v}}$ pollard. The suspensions in shake flasks, were incubated on a shaker incubator at $30^{\circ} \mathrm{C}$ and $150 \mathrm{rpm}$ for $36 \mathrm{~h}$. Before the enzyme being assayed was separated from the biomass, $0.2 \%$ sodium azide was added. Biomass was then separated by centrifugation at $12000 \mathrm{x}$ g for $20 \mathrm{~min}$. The clear supernatant was used to estimate enzyme activities and stored at $-20^{\circ} \mathrm{C}$.

Enzyme Activity and Reducing Sugar Assays. Xylanase activity was measured according to the method of Rickard and Laughlin (1980). All assays were carried out in McIlvaine (citrate-phosphate) buffer $\mathrm{pH}$ 7.2. Endo- $\beta$ 1,4-D-xylan xylanohydrolase activity was assayed by using $1 \%$ solution of oat spelt xylan as the substrate. Reducing sugars produced by the reaction were assayed by the DNS method (Miller 1959). One unit of enzyme activity is defined as the amount of enzyme producing $1 \mu \mathrm{mol}$ xylose equivalents per minute under the given conditions. Sugar composition (saccharides) of untreated and pretreated pollards was determined by Analytical Laboratory of Indonesian Research Institute for Animal Production using HPLC. Sugar pack column from Waters was used for the HPLC, while double distilled $\mathrm{H}_{2} \mathrm{O}$ was used as the mobile phase and run at $90^{\circ} \mathrm{C}$. Oligosaccharide composition of pretreated pollards was determined, while oat meal was not.

Protein Concentration Assay. Protein concentration was determined by the dye-binding method of Bradford (1976) with bovine serum albumin as the standard.

Lignocellulose Content. The lignocellulose content was determined by Analytical Laboratory of Indonesian Research Institute for Animal Production, Bogor, according to the method of Van Soest and Robertson (1968).

Statistical Analysis. Analysis variance of enzyme activity, protein concentration, and specific activity on pollard-treated and oat was carried out using one way analysis (MINITAB $\left.^{\circledR} 15\right)$. The correlation values of reducing sugar content of pollard treated over different soaking period and the specific enzyme activity obtained were also analyzed. Results come from three replicates.

\section{RESULTS}

Results from different kinds of substrates show that the highest enzyme activity was observed from untreated-pollard (Table 1) that was not significantly different with that from water-soaked pollard (157 $\mathrm{U} \mathrm{ml}^{-1}$ vs $128 \mathrm{U} \mathrm{ml}^{-1}$ ). Since the protein content in water-soaked pollard was higher than that in untreated-pollard, the specific enzyme activity in untreated-pollard (718 $\mathrm{U} \mathrm{mg}^{-1}$ ) was significantly the highest compared with in other substrates $(\mathrm{P}<0.05)$. Producing xylanase using oatmeal as a sole carbon source was not an effective way because, the enzyme activity and specific

Table 1 Enzyme activity, protein concentration, and specific activity of xylanase produced in pretreated pollards (untreated, water, and NaOH) and oatmeal

\begin{tabular}{lccc}
\hline Kinds of pretreatment & Enzyme activity $\left(\mathrm{U} \mathrm{ml}^{-1}\right)$ & Protein $\left(\mu \mathrm{g} \mathrm{ml}^{-1}\right)$ & Specific activity $\left(\mathrm{U} \mathrm{mg}^{-1}\right)$ \\
\hline Untreated-pollard (control) & $157 \mathrm{c}^{*}$ & $219 \mathrm{bc}$ & $718 \mathrm{c}$ \\
Water-soaked pollard & $128 \mathrm{~b}$ & $261 \mathrm{c}$ & $493 \mathrm{~b}$ \\
NaOH-soaked pollard & $5 \mathrm{a}$ & $194 \mathrm{ab}$ & $26 \mathrm{a}$ \\
Oatmeal & $6 \mathrm{a}$ & $147 \mathrm{a}$ & $41 \mathrm{a}$ \\
\hline
\end{tabular}

*Different alphabet in the same column shows significantly different $(\mathrm{P}<0.05)$. 
activity was only $6.0 \mathrm{U} \mathrm{ml}^{-1}$ and $41 \mathrm{U} \mathrm{mg}^{-1}$, respectively. Compared to all substrates used in this research, sodium hydroxide-soaked pollard had the lowest activity and specific activity, $5 \mathrm{U} \mathrm{ml}^{-1}$ and $26 \mathrm{U} \mathrm{mg}^{-1}$, respectively $(\mathrm{P}<0.05)$.

Lignocellulose content and reducing sugar in all substrates were determined to investigate the correlation between the enzyme production and the substrate composition. As predicted before, pretreatments decreased the reducing sugars (Table 2 and 3 ). The highest lignocellulose contents were observed on $\mathrm{NaOH}$-soaked pollard that the only pollard where xylan was detected. It seems that the treatment opens the lignocellulose compounds or solubilized the hemicellulose, resulting the xylan was not detected in pretreated-pollards in HPLC.

Results from different soaking period experiment showed that the highest enzyme activity was still obtained from untreated pollard. The reducing sugar available in pollard was decreasing when the washing period increased (Fig 1). It also gave an interesting result that the longer the washing period, the lower the specific enzyme activity. The statistical analysis showed that there was a highly significant $(\mathrm{P}<0.0001)$ correlation between reducing sugar and washing period and $\mathrm{R}^{2}=0.9155$.

\section{DISCUSSION}

Bacillus pumilus PU4-2 has received considerable attention as an industrial aid, particularly in producing xylanase and probiotic for monogastric animals. Recently, this microorganism was reported to be capable of producing xylanase using pollard as the sole carbon source. As a by-product from flour mills, pollard is an economically useable as a substrate in enzyme induction.

The results from the first experiments were unexpected. Pretreatment methods did not produce the optimum activity in this research. Additionally, oatmeal was not a viable medium to increase assayable xylanase. Meanwhile, untreated pollard used as a control showed the highest enzyme activity and also specific enzyme activity. From our lignocellulose and HPLC data, it was concluded that pretreatment methods washed out some soluble oligosaccharides involved in the presumed enzyme induction. Soaking pollard in water was undertaken to reduce the reducing sugar that may repress the presumed gene expression. Apparently, it was not only reduced the reducing

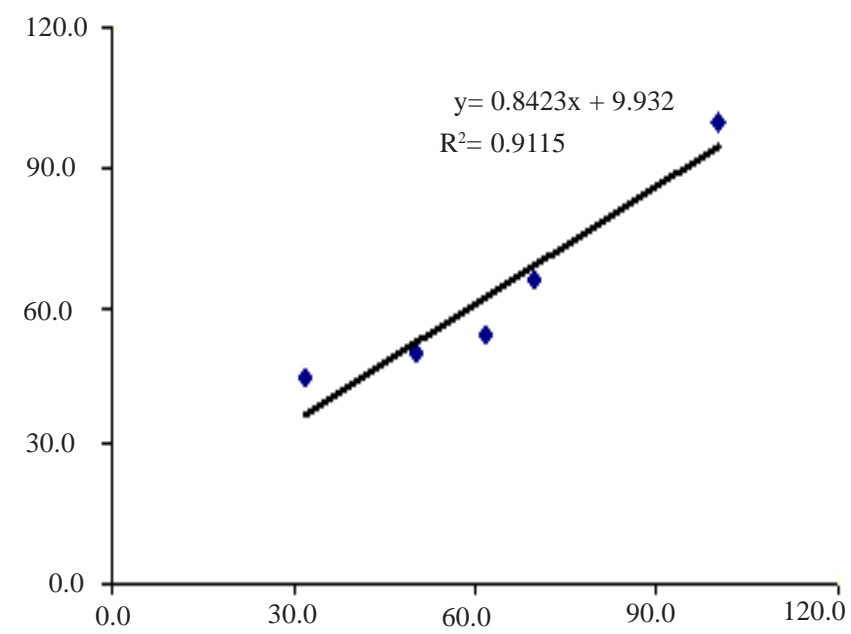

Fig 1 Correlation relative specific activity of xylanase detected in different period of water-soaked pollards towards their relative reducing sugar content. Period of soaking: 0, 5, 10, 15, and 20 minutes.

sugar but it also reduced the water-soluble inducer molecules, the oligosaccharide content of water-soaked pollard was lower than untreated-pollard (0.05 vs $0.34 \% \mathrm{w} / \mathrm{w})$.

Pretreatment using sodium hydroxide maximized all of the lignocellulose components. It is assumed that this high alkali pretreatment might have dissolved all of the small oligosaccharides, those washed out during water rinsing for neutralizing the substrate to $\mathrm{pH}$ 7. This explains why the lignocellulose content was the highest among other substrate because there are only long-chains oligosaccharides present in this substrate, making it harder for the hemicellulolytic microbes to digest. However, this condition should still be suitable for cellulase production, since the crystalline structure of cellulose was disrupted. The disruption opened the hemicellulose molecules (xylan) to be detected in HPLC.

Oatmeal had the lowest lignocellulose content (Table 1). Compared to other substrates, hemicellulose available in this material was the lowest and this is apparently not enough to induce the xylanase production in assayable quantities. Oatmeal probably could induce amylase which is not produced by $B$. pumilus PU4-2. This explains why the activity gained using this material as carbon source was very low.

Generally, a control is run to standardize a set of results. Surprisingly, the control in this research gave the best result. The fact that having the best result from the control was not a common occurrence. Therefore a trial was done to confirm

Table 2 Reducing sugar and lignocellulose contents in pretreated-pollards and oatmeal

\begin{tabular}{lccrr}
\hline Kinds of pretreatment & $\begin{array}{c}\text { Reducing sugar } \\
(\% \text { w/w) }\end{array}$ & \multicolumn{2}{c}{ Lignocellulose content (\% w/w) } \\
\cline { 3 - 5 } & 2.2 & 2.78 & Hemicelluloses & Cellulose \\
\hline Untreated pollard (control) & 1.3 & 2.40 & 29.15 & 8.17 \\
Water-soaked pollard & 1.1 & 9.05 & 26.40 & 7.99 \\
NaOH-soaked pollard & 1.2 & 0.95 & 43.99 & 29.13 \\
Oatmeal & & & 9.00 & 1.62 \\
\hline
\end{tabular}

Table 3 The composition of mono, oligo and poly-saccharides in pretreated-pollards

\begin{tabular}{lccc}
\hline \multirow{2}{*}{ Kinds of pretreatment } & \multicolumn{3}{c}{ Oligosaccharide content (\% w/w) } \\
\cline { 2 - 4 } & Monosaccharide & Oligosaccharide & Xylan \\
\hline Untreated pollard (control) & 2.11 & 0.34 & ND \\
Water-soaked pollard & 1.28 & 0.05 & ND \\
NaOH-soaked pollard & 0.12 & 0.20 & 0.14 \\
\hline ND: not detected. & \multicolumn{3}{l}{}
\end{tabular}


the result obtained from the first findings. Substrate used in this following trial was water-soaked pollard with various soaking period compared to untreated pollard.

In the following trial, untreated pollard still gave the highest activity. With this result, it is obvious that reducing sugar had an insignificant influence compared to inducer molecules. This hypothesis was supported with the correlation experiment of reducing sugar content toward specific enzyme activity (Fig 1). It was reported by Sachslehner et al. (1998) that xylanase was still produced by $S$. rolfsii in the media containing 540 ppm kind of monosaccharides (glucose, xylose or mannose). Our untreated and water-soaked pollard media contained respectively mono-saccharides 660 and $430 \mathrm{ppm}$, those concentration did not repress the formation of xylanase.

The interesting result could be observed in the following trial, the period of soaking time in water-soaked pollard, was the more washing period, the lower reducing sugar, and specific activity obtained. The lower reducing sugar occurred due to the more soluble and metabolizable oligosaccharide washed out when the pollard was filtered using cotton cloth. The reducing sugar content available in production medium has a highly significant correlation with the specific activity in this following experiment $\left(\mathrm{P}<0.0001 ; \mathrm{R}^{2}=0.9115\right)$ (Fig 1). It is believed that the soluble molecules washed out by pretreatment methods were important due to lower enzyme activity and specific activity compared to untreated pollard.

The enzymes involved in substrate degradation were generally inducible. They were formed only when the corresponding substrate was present in the media. Fungal, bacterial and actinomycete xylanases were generally induced, whether induced by xylan, xylobiose, xylose or by lignocellulosic residues that contain xylan (Lemos and Pereira 2002). Since the polysaccharides were far too large to pass through the cell membrane and triggered the response in the microbial cell leading to the enhanced synthesis of xylanase. It was generally believed that low-molecular-mass soluble catabolites which were released from the polymeric compounds of the action of low, constitutive, amounts of this hydrolase and which could easily enter the cell, provided signal of the presence of an extracellular substrate and the stimulus for the accelerated synthesis of the enzyme (Sachslehner et al. 1998). The same authors also noted that xylobiose was the best inducer to produce xylanase by $S$. rolfsii and it is clearly indicated that the xylobiose content washed out by pretreatment methods influenced the enzyme produced by B. pumilus PU 4-2.

The protein content of the filtrate from the culture shows that different substrate produced different protein content. However, the highest protein not came from the highest enzyme activities, the protein content in the filtrate may be from the soluble protein of the substrate or other enzymes such as cellulose and glycosidases.

Untreated pollard as the best substrate for xylanase production by $B$. pumilus PU4-2 gave a lot of advantages. By using untreated pollard, it would be economically more efficient than using pretreated pollard and also save more time because there were no steps needed to prepare this material as substrate for enzyme production. Another advantage, untreated pollard was more environmentally friendly than sodium hydroxide-soaked pollard because there were no sodium hydroxide residues that could pollute the environmental, especially rivers where it could affect people that still using water from rivers to fulfill their primary needs.

\section{ACKNOWLEDGEMENT}

Authors wish to thank Indonesian Research Institute for Animal Production for their financial support on this research. The funding was from the Indonesia Agricultural Department Budgett.

\section{REFERENCES}

Bradford M. 1976. A rapid and sensitive method for the quantitation of microgram quantities of protein utilizing the protein-dye binding. Anal Biochem 72:248-254.

Chocht M. 2006. Enzyme for the feed industry. World Poultry Sci J 62:515.

Choi SD, Hong HB, Chang YS. 2003. Adsorption of halogenated aromatic pollutants by a protein released from Bacillus pumilus. Water Res 37:4004-4010.

Degrassi G, Okeke BC, Bruschi CV, Venturi V. 1998. Purification and characterization of an acetyl xylan esterase from Bacillus pumilus. Appl Environ Microbiol 64:789-792.

Flores ME, Perez R, Huitron C. 1997. $\beta$-Xylosidase and xylanase characterization and production by Streptomyces sp. CH-M-1035. Lett Appl Microbiol 24:410-416.

Hong HB, Chang YS, Choi SD, Nam IH, Lee YE. 2001. Isolation and characterization of a cell-associated protein of Bacillus pumilus PH-01. Appl Microbiol Biotechnol 56:402-405.

Irawan. 1999. Karakterisasi xilanase bakteri xilanolitik termofilik yang diisolasi dari sumber air panas Gunung Pancar, Bogor [Thesis]. Bogor: Fakultas Pasca Sarjana, Institut Pertanian Bogor.

Ketaren PP, Purwadaria P, Sinurat AP. 2002. Penampilan ayam pedaging yang diberi ransum basal dedak atau polar dengan atau tanpa suplementasi enzim xilanase. In: Prosiding Seminar Nasional Teknologi Peternakan dan Veteriner. Bogor, 30 Sep - 1 Okt 2002. p 306-308.

Kotchoni OS, Shonukan OO, Gachomo WE. 2003. Bacillus pumilus BpCRI 6, a promising candidate for cellulase production under condition of catabolite repression. Afr J Biotechnol 2:140-146.

Lemos JLS, Pereira N Jr. 2002. Influence of some sugars on xylanase production by Aspergillus awamori in solid state fermentation. Braz Arch Biol Technol 45:431-437.

Lima DU, Santos HP, Tiné MA, Molle FRD, Buckeridge MS. 2001. Patterns of expression of cell wall related genes in sugarcane. Gen Mol Biol 24:191-198.

Miller GL. 1959. Use of dinitrosalicylic acid reagent for determination of reducing sugar. Anal Biochem 31:426-428.

Mosier N, Wyman C, Dale B, Elander R, Lee YY, Holtzapple M. 2005. Features of promising technologies for pretreatment of lignocellulosic biomass. Biores Technol 96:673-686.

Nuyens F, van Zyl WH, Iserentant D, Verachtert H, Michiels C. 2001. Heterologous expression of the Bacillus pumilus endo- $\beta$-xylanase (xynA) gene in the yeast Saccharomyces cerevisiae. Appl Microbiol Biotechnol 56:431-434.

Purwadaria T, Ardiningsih P, Ketaren PP, Sinurat AP. 2004a. Isolasi dan penapisan bakteri mesofil dari rayap. J Mikrobiol Indones 9:59-62.

Purwadaria T, Kumalasari A, Ketaren PP, Sinurat AP. 2004b. Optimization of cellulase production with Penicillium nalgiovense S11 grown on pretreated wheat pollard. Biotropia 23:1-12.

Rickard PAD, Laughlin TA. 1980. Detection and assay xylanolytic enzymes in a Cellulomonas isolate. Biotechnol Lett 2:363-368. 
Sachslehner A, Nidetzky B, Kulbe KD, Haltrich D. 1998. Induction of mannanase, xylanase, and endoglucanase activities in Sclerotium rolfsii. Appl Environ Microbiol 64:594-600.

Shin Y, Son K, Yoo DI. 2000. Structural changes in tencel by enzymatic hydrolysis. J Appl Polym Sci 76:1644-1651.

Tuncer M. 2000. Characterization of endoxylanase activity from Thermonospora fusca BD25. Turk J Biol 24:737-752.
Van Soest PJ, Robertson JB. 1968. System of analysis for evaluating fibrous feeds. In: WJ Pigden (ed). Standardization of Analytical Methodology for Feed. Cent. Toronto, Canada IDRC. 134e.

Wong KKY, Tan LUL, Saddler JN. 1988. Multiplicity of 3-1,4-xylanase in microorganisms: functions and applications. Microbiol Rev 52:305317. 